\title{
Systematic Review \\ Meta-Analysis of Neoadjuvant Immunotherapy for Patients with Resectable Non-Small Cell Lung Cancer
}

\author{
Christopher Cao ${ }^{1,2, *(D)}$, Anthony Le ${ }^{1}$, Matthew Bott ${ }^{3}$, Chi-Fu Jeffrey Yang ${ }^{4}$, Dominique Gossot ${ }^{5}$, Franca Melfi ${ }^{6}$, \\ David H. Tian ${ }^{7}$ and Allen Guo ${ }^{1}$ \\ 1 Department of Cardiothoracic Surgery, Royal Prince Alfred Hospital, Sydney University, \\ Sydney, NSW 2050, Australia; anthony.le1@health.nsw.gov.au (A.L.); z5213592@student.unsw.edu.au (A.G.) \\ 2 Chris O'Brien Lifehouse Hospital, Sydney, NSW 2050, Australia \\ 3 Thoracic Surgery Service, Memorial Sloan Kettering Cancer Center, New York, NY 10065, USA; \\ bottm@mskcc.org \\ 4 Division of Thoracic Surgery, Massachusetts General Hospital, Boston, MA 02114, USA; \\ cjyang@mgh.harvard.edu \\ 5 Department of Thoracic Surgery, Institut du Thorax Curie-Montsouris, 75014 Paris, France; \\ dominique.gossot@imm.fr \\ 6 Robotic Multispecialty Center for Surgery Robotic, Minimally Invasive Thoracic Surgery, University of Pisa, \\ 56124 Pisa, Italy; franca.melfi@unipi.it \\ 7 Department of Anaesthesia and Perioperative Medicine, Westmead Hospital, Sydney, NSW 2145, Australia; \\ david.tian@health.nsw.gov.au \\ * Correspondence: Christopher.Cao@health.nsw.gov.au; Tel.: +61-29-515-6111
}

Citation: Cao, C.; Le, A.; Bott, M.; Yang, C.-F.J.; Gossot, D.; Melfi, F.; Tian, D.H.; Guo, A. Meta-Analysis of Neoadjuvant Immunotherapy for Patients with Resectable Non-Small Cell Lung Cancer. Curr. Oncol. 2021, 28, 4686-4701. https://doi.org/ 10.3390 /curroncol28060395

Received: 3 October 2021

Accepted: 10 November 2021

Published: 14 November 2021

Publisher's Note: MDPI stays neutral with regard to jurisdictional claims in published maps and institutional affiliations.

Copyright: (c) 2021 by the authors. Licensee MDPI, Basel, Switzerland. This article is an open access article distributed under the terms and conditions of the Creative Commons Attribution (CC BY) license (https:// creativecommons.org/licenses/by/ $4.0 /)$.

\begin{abstract}
Purpose: Immunotherapy has created a paradigm shift in the treatment of metastatic non-small cell lung cancer (NSCLC), overcoming the therapeutic plateau previously achieved by systemic chemotherapy. There is growing interest in the utility of immunotherapy for patients with resectable NSCLC in the neoadjuvant setting. The present systematic review and meta-analysis aim to provide an overview of the existing evidence, with a focus on pathological and radiological response, perioperative clinical outcomes, and long-term survival. Methods: A systematic review was conducted using electronic databases from their dates of inception to August 2021. Pooled data on pathological response, radiological response, and perioperative outcomes were meta-analyzed where possible. Results: Eighteen publications from sixteen studies were identified, involving 548 enrolled patients who underwent neoadjuvant immunotherapy, of whom 507 underwent surgery. Pathologically, 52\% achieved a major pathological response, $24 \%$ a complete pathological response, and $20 \%$ reported a complete pathological response of both the primary lesion as well as the sampled lymph nodes. Radiologically, $84 \%$ of patients had stable disease or partial response. Mortality within 30 days was $0.6 \%$, and morbidities were reported according to grade and frequency. Conclusion: The present meta-analysis demonstrated that neoadjuvant immunotherapy was feasible and safe based on perioperative clinical data and completion rates of surgery within their intended timeframe. The pathological response after neoadjuvant immunotherapy was superior to historical data for patients who were treated with neoadjuvant chemotherapy alone, whilst surgical and treatment-related adverse events were comparable. The limitations of the study included the heterogenous treatment regimens, lack of long-term follow-up, variations in the reporting of potential prognostic factors, and potential publication bias.
\end{abstract}

Keywords: immunotherapy; meta-analysis; non-small cell lung cancer; neoadjuvant therapy

\section{Introduction}

The emergence of immune checkpoint inhibitors (ICIs) transformed the landscape of treatment pathways for patients with metastatic non-small cell lung cancer (NSCLC) after encouraging results were reported from randomized controlled trials [1]. For patients with resectable NSCLC, the therapeutic plateau achieved by systemic chemotherapy as 
an adjuvant treatment reported a modest improvement of $5 \%$ over five years [2]. In the context of favorable outcomes identified in the metastatic NSCLC population, there is growing enthusiasm for neoadjuvant immunotherapy in patients with resectable NSCLC. The proposed benefits of immunotherapy prescribed in the neoadjuvant setting include the increased release of neoantigens from the tumor to stimulate the expansion of specific T-cells, enhanced control of micro-metastases, and enabling the assessment of biologic and immunologic responses of the tumor from resected specimens [3].

Due to the relative paucity of robust clinical data, there is an urgent need to assess the existing literature to analyze the feasibility, safety, and efficacy of neoadjuvant immunotherapy. The primary aims of the present systematic review and meta-analysis were to identify the pathological and radiological response rates of neoadjuvant ICIs. Secondary endpoints included perioperative mortality, surgical morbidity, treatment-related adverse events, delays in surgery, and the overall long-term and disease-free survival outcomes.

\section{Materials and Methods}

\subsection{Search Strategy}

Our methods adhered to the guidelines set forth in the Preferred Reporting Items for Systematic Review and Meta-Analyses: The PRISMA Statement. A systematic review was performed using online databases from their dates of inception to August 2021, including EMBASE, Ovid Medline, and all EBM Reviews. Search terms included neoadjuvant* and ("NSCLC" or "carcinoma, non-small cell lung" or "Non small cell lung") and ("surg*" or "resect" or "lobectomy" or "VATS" or "thoracic surgery, video-assisted") as either Medical Subject Headings or keywords. Reference lists of all retrieved full texts were screened for further identification of potentially relevant studies.

\subsection{Selection Criteria and Data Extraction}

Selected studies included those in which patients with histologically proven NSCLC were treated with ICI prior to surgical resection and provided data on radiological and pathological response. Publications were limited to human subjects and written in English. Case studies involving 10 or fewer patients, conference abstracts, and poster presentations were excluded. Two investigators (A.G. and A.L.) independently reviewed each retrieved article. Discrepancies between the two reviewers were resolved by discussion and consensus after review by the senior investigator (C.C.).

\subsection{Statistical Analysis}

Meta-analysis of proportions or means was performed for categorical or continuous variables via generalized linear mixed models, as appropriate [4]. A random-effects model was applied to account for differing local surgical and immunotherapy protocols. Pooled data are presented as $\mathrm{N}(\%)$ with $95 \%$ confidence intervals (CI). $\mathrm{I}^{2}$ statistic was used to estimate the percentage of total variation across studies due to heterogeneity rather than chance. Thresholds for $\mathrm{I}^{2}$ values for low, moderate, and high heterogeneity were considered as $0-49 \%, 50-74 \%$ and $\geq 75 \%$, respectively. Specific analyses considering confounding factors were not possible because raw data were not available. All $p$-values were 2-sided, and $\leq 0.05$ were considered statistically significant. All statistical analyses were conducted with Review Manager Version 5.1.2 (Cochrane Collaboration, Software Update, Oxford, UK) or R Version 4.0.2 (R Foundation for Statistical Computing, Vienna, Austria).

\section{Results}

\subsection{Quantity and Quality of Trials}

A total of 4143 references were identified through the electronic search; 2914 potentially relevant articles remained for screening after the removal of duplicated studies. After applying the selection criteria, 33 studies remained for full assessment, and 18 publications from 16 studies were selected for quantitative analysis [5-22]. Two publications reported on the same trials with a focus on different clinical outcomes $[6,7,12,13]$. Eleven publications 
from nine studies were prospectively registered in national clinical trial registries [5-15]. There was one randomized controlled trial, which compared neoadjuvant nivolumab with nivolumab and ipilimumab prior to surgical resection [8]. Neoadjuvant immunotherapy agents included durvalumab, nivolumab, ipilimumab, pembrolizumab, atezolizumab, sintilimab, and camrelizumab. A summary of the search strategy is presented in the PRISMA chart in Supplementary Figure S1, and a summary of the study characteristics is presented in Table 1. 
Table 1. Study characteristics of trials on neoadjuvant immunotherapy for patients with resectable non-small cell lung cancer

\begin{tabular}{|c|c|c|c|c|c|c|}
\hline Study & Institution & $\begin{array}{l}\text { Recruitment } \\
\text { Period }\end{array}$ & F/U (Months) & Immunotherapy & Chemotherapy & $\begin{array}{c}\text { Adjuvant } \\
\text { Immunotherapy }\end{array}$ \\
\hline Rothschild, 2021 [5] & 14 institutions in Sweden & $6 / 2016-1 / 2019$ & 29 & Durvalumab (750 mg) 2 cycles & Cisplatin + docetaxel & Durvalumab 26 cycles \\
\hline $\begin{array}{l}\text { NADIM } \\
\text { Provencio, } 2021 \text { [6] } \\
\text { Roman, 2021 [7] }\end{array}$ & 18 institutions in Spain & $4 / 2017-8 / 2018$ & 24 & Nivolumab (360 mg) 3 cycles & Paclitaxel + carboplatin 3 cycles & $\begin{array}{l}\text { Nivolumab ( } 240 \mathrm{mg} \mathrm{q} 2 \mathrm{w} \\
\text { for } 4 \text { months then } 480 \mathrm{mg} \\
\mathrm{q} 4 \mathrm{w} \text { for } 8 \text { months) }\end{array}$ \\
\hline $\begin{array}{l}\text { NEOSTAR } \\
\text { Cascone, } 2021 \text { [8] }\end{array}$ & $\begin{array}{c}\text { MD Anderson } \\
\text { Cancer Center, USA }\end{array}$ & $6 / 2017-11 / 2018$ & 22 & $\begin{array}{l}\text { Nivolumab ( } 3 \mathrm{mg} / \mathrm{kg} \text { on D1, } \\
15,29) 3 \text { cycles or Nivolumab } \\
3 \text { cycles + Ipilimumab } \\
\text { (1 mg/kg on D1 only) }\end{array}$ & NS & 19 \\
\hline $\begin{array}{l}\text { NEOMUN } \\
\text { Eichhorn, 2021 [9] }\end{array}$ & $\begin{array}{c}\text { Heidelberg } \\
\text { University Hospital, } \\
\text { Germany }\end{array}$ & $5 / 2018-3 / 2020$ & NS & $\begin{array}{l}\text { Pembrolizumab }(200 \mathrm{mg}) \\
2 \text { cycles }\end{array}$ & NS & NS \\
\hline Tong, $2021[10]$ & $\begin{array}{l}\text { Mayo Clinic; Dartmouth- } \\
\text { Hitchcock; Duke } \\
\text { University, USA }\end{array}$ & $4 / 2017-2 / 2019$ & 11 & $\begin{array}{l}\text { Pembrolizumab }(200 \mathrm{mg}) \\
2 \text { cycles }\end{array}$ & NS & Pembrolizumab 4 cycles \\
\hline Shu, 2020 [11] & $\begin{array}{l}\text { Columbia University; } \\
\text { MGH; BWH; Vanderbilt } \\
\text { University Medical } \\
\text { Center, USA }\end{array}$ & 5/2016-3/019 & 13 & $\begin{array}{l}\text { Atezolizumab }(1200 \mathrm{mg}) \\
4 \text { cycles }\end{array}$ & Paclitaxel + carboplatin 4 cycles & NS \\
\hline $\begin{array}{l}\text { Bott, } 2019 \text { [12] } \\
\text { Forde, } 2018[13]\end{array}$ & $\begin{array}{c}\text { Johns Hopkins; MSKCC, } \\
\text { USA }\end{array}$ & $8 / 2015-10 / 2016$ & 20 & Nivolumab (3 mg $/ \mathrm{kg}) 2$ cycles & NS & NS \\
\hline Gao, 2020 [14] & PUMC & $3 / 2018-3 / 2019$ & 3 & Sintilimab (200 mg) 2 cycles & NS & Sintilimab \\
\hline Yang, 2018 [15] & $\begin{array}{l}\text { Duke University Medical } \\
\text { Centre, USA }\end{array}$ & $3 / 2013-12 / 2015$ & 24 & $\begin{array}{c}\text { Ipilimumab }(10 \mathrm{mg} / \mathrm{kg}) \\
2 \text { cycles }\end{array}$ & $\begin{array}{l}\text { Paclitaxel + cisplatin or } \\
\text { carboplatin } 3 \text { cycles }\end{array}$ & NS \\
\hline Wang, 2021 [16] & $\begin{array}{l}\text { Zhejiang Cancer } \\
\text { Hospital, China }\end{array}$ & $9 / 2019-7 / 2020$ & NS & $\begin{array}{l}\text { Nivolumab (200 mg), } \\
\text { pembrolizumab }(100 \mathrm{mg}), \\
\text { camrelizumab }(200 \mathrm{mg}) \\
2 \text { cycles }\end{array}$ & Paclitaxel + carboplatin q3w & NS \\
\hline Shen, 2021 [17] & $\begin{array}{l}\text { Zhejiang Cancer } \\
\text { Hospital, China }\end{array}$ & $6 / 2019-7 / 2020$ & 7 & $\begin{array}{l}\text { Pembrolizumab }(2 \mathrm{mg} / \mathrm{kg}) \\
2 \text { cycles }\end{array}$ & Paclitaxel + carboplatin 2 cycles & NS \\
\hline
\end{tabular}


Table 1. Cont.

\begin{tabular}{|c|c|c|c|c|c|c|}
\hline Study & Institution & $\begin{array}{l}\text { Recruitment } \\
\text { Period }\end{array}$ & F/U (Months) & Immunotherapy & Chemotherapy & $\begin{array}{c}\text { Adjuvant } \\
\text { Immunotherapy }\end{array}$ \\
\hline Jiang, $2021[18]$ & $\begin{array}{c}\text { Shanghai Chest Hospital, } \\
\text { China }\end{array}$ & $9 / 2018-4 / 2020$ & NS & $\begin{array}{l}\text { Pembrolizumab or nivolumab } \\
3 \text { cycles }\end{array}$ & NS & Variable \\
\hline Huang, 2021 [19] & $\begin{array}{l}\text { Qingdao University } \\
\text { Hospital, China }\end{array}$ & $6 / 2019-12 / 2020$ & NS & Nivolumab $(3 \mathrm{mg} / \mathrm{kg}) 2$ cycles & NS & NS \\
\hline Duan, 2021 [20] & $\begin{array}{l}\text { Tangdu Hospital; } \\
\text { Chongqing Medical } \\
\text { University, China }\end{array}$ & $6 / 2018-6 / 2020$ & NS & $\begin{array}{l}\text { Sintilimab or nivolumab or } \\
\text { pembrolizumab, 3-4 cycles }\end{array}$ & $\begin{array}{c}\text { Pemetrexed + cisplatin or } \\
\text { Paclitaxel }+ \\
\text { nedaplatin or Gemcitabine + } \\
\text { nedaplatin or Paclitaxel + } \\
\text { Carboplatin 3-4 cycles }\end{array}$ & NS \\
\hline Chen, 2021 [21] & $\begin{array}{c}\text { Shanghai Chest Hospital, } \\
\text { China }\end{array}$ & $1 / 2019-3 / 2020$ & 18 & $\begin{array}{l}\text { Pembrolizumab } 4 \text { cycles or } \\
\text { nivolumab } 2 \text { cycles }\end{array}$ & Carboplatin and paclitaxel & Variable \\
\hline Chen, 2021 [22] & $\begin{array}{c}\text { Tianjin Medical } \\
\text { University } \\
\text { Cancer Institute and } \\
\text { Hospital }\end{array}$ & $1 / 2019-5 / 2020$ & 13 & $\begin{array}{c}\text { Pembrolizumab }(2 \mathrm{mg} / \mathrm{kg}) \\
2 \text { cycles } \mathrm{q} 3 \mathrm{w}\end{array}$ & $\begin{array}{c}\text { Cisplatin + paclitaxel liposome or } \\
\text { pemetrexed q3w }\end{array}$ & NS \\
\hline
\end{tabular}

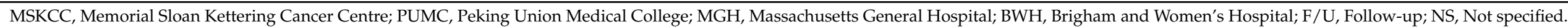




\subsection{Patient Characteristics}

In total, 548 patients were treated with at least one cycle of neoadjuvant immunotherapy, with 507 patients $(96 \%)$ undergoing subsequent surgery. The overall incidence of male patients was $73.7 \%$, and the interquartile range of age across different studies was 61.5-65.5. Overall, $81.7 \%$ of patients were either former or current smokers. Histologically, $56.6 \%$ of patients had squamous cell carcinoma, $36.9 \%$ had adenocarcinoma, and $4.2 \%$ had other subtypes. The clinical stage was reported according to either the 7th or 8th edition of the TNM staging system, with $78.0 \%$ of patients reported as clinical stage IIIA and $1.0 \%$ of patients as stage IIIB $[23,24]$. Further details of patient characteristics are summarized in Table 2. 
Table 2. A summary of baseline patient characteristics in selected studies on neoadjuvant immunotherapy for resectable non-small cell lung cancer.

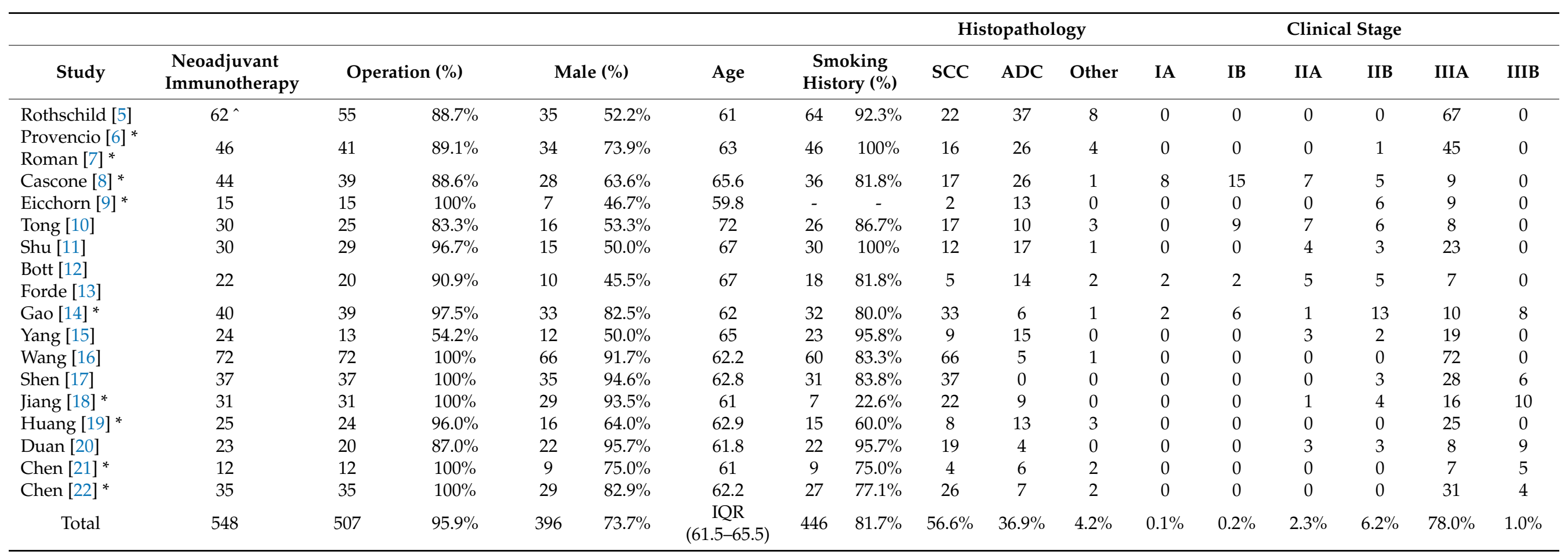

${ }^{*}$ AJCC 8th edition TNM staging system; ${ }^{\wedge} 62 / 67$ enrolled patients received neoadjuvant immunotherapy; SCC, squamous cell carcinoma; ADC, adenocarcinoma. 


\subsection{Surgical Approach and Resection Type}

The most common type of resection was lobectomy (67.5\%), followed by bilobectomy $(12.1 \%)$, and pneumonectomy (8.6\%). Surgical access was performed with minimal invasiveness through a video-assisted or robotic-assisted approach in $47.4 \%$ of operations, but $12.4 \%$ patients underwent a conversion to open thoracotomy after an intended minimally invasive approach. Overall, thoracotomy was performed in $51.7 \%$ of all operations. A complete microscopic resection (R0) was reported in $97.3 \%$ of all patients. The interquartile time interval from the final dose of immunotherapy to the time of operation was 27-32 days, and $2.0 \%$ of patients were delayed from their intended time of operation after treatment with neoadjuvant immunotherapy. The interquartile range of operative duration was 171-239 min. A total of 11 transfusion events occurred in 417 patients (6.9\%). A summary of surgical details is presented in Table 3 . 
Table 3. A summary of operative details for patients who underwent neoadjuvant immunotherapy in the treatment of resectable non-small cell lung cancer.

\begin{tabular}{|c|c|c|c|c|c|c|c|c|c|c|c|c|c|c|c|c|c|c|}
\hline \multirow[b]{2}{*}{ Study } & \multicolumn{3}{|c|}{ Resection Margin } & \multicolumn{5}{|c|}{ Type of Surgery } & \multicolumn{5}{|c|}{ Surgical Approach } & \multicolumn{2}{|c|}{ Final Immunotherapy to Surgery } & \multirow[b]{2}{*}{ Time (min) } & \multicolumn{2}{|c|}{ Blood Loss } \\
\hline & Ro & R1 & R2 & Pneumonectomy & Bilobectomy & Lobectomy & $\begin{array}{c}\text { Sleeve } \\
\text { Lobectomy }\end{array}$ & Wedge & Other & Exploratory & Thoracotomy & MIS & Conversion to Open & Median Days & Delay (n) & & Blood Loss (mL) & Transfusion \\
\hline Rothschild [5] & 51 & 3 & 1 & 5 & 7 & 43 & - & - & - & - & - & - & - & - & - & - & - & - \\
\hline $\begin{array}{l}\text { Provencio [6], } \\
\text { Roman [7] }\end{array}$ & 41 & 0 & 0 & 3 & 3 & 32 & 3 & 0 & - & 0 & $24 / 41$ & $17 / 41$ & $4 / 41$ & - & 0 & 195 & - & 1 \\
\hline Cascone [8] & 39 & 0 & 0 & - & - & - & - & - & - & - & - & - & - & 31 & 8 & - & - & - \\
\hline Eicchorn [9] & 15 & 0 & 0 & 0 & 0 & 15 & 0 & 0 & - & 0 & - & - & - & - & 1 & - & - & - \\
\hline Tong [10] & 22 & 3 & 0 & 3 & 1 & 18 & 2 & - & 1 & - & $7 / 25$ & $18 / 25$ & $5 / 25$ & 26 & 1 & 305 & - & 2 \\
\hline Shu [11] & 26 & - & - & 3 & 4 & 19 & 0 & 0 & - & 3 & $14 / 29$ & $12 / 29$ & - & 27 & 0 & - & - & 2 \\
\hline Gao [14] & 36 & 0 & 1 & 13 & 5 & 18 & 1 & 0 & - & 2 & $29 / 39$ & $10 / 39$ & - & - & 2 & - & - & - \\
\hline Yang [15] & 13 & 0 & 0 & 1 & 1 & 10 & 0 & 1 & - & - & $4 / 13$ & $9 / 13$ & $3 / 13$ & - & 2 & - & - & 2 \\
\hline Wang [16] & - & - & - & - & - & - & - & - & - & - & - & - & - & - & 0 & - & - & - \\
\hline Shen [17] & 37 & 0 & 0 & 2 & 7 & 22 & 6 & - & - & - & $12 / 37$ & $25 / 37$ & - & - & - & 184 & - & - \\
\hline Jiang [18] & 24 & 4 & 3 & 2 & 4 & 18 & 7 & 0 & 0 & 0 & $23 / 31$ & $8 / 31$ & 1 & 34 & - & 158 & 200 & 2 \\
\hline Huang [19] & 23 & 1 & 0 & 1 & 3 & 19 & - & - & 1 & - & $0 / 24$ & $24 / 24$ & - & 29 & 0 & 196 & 92 & - \\
\hline Duan [20] & 19 & 1 & 0 & 2 & 2 & 11 & 5 & 0 & - & 0 & $6 / 20$ & $14 / 20$ & $2 / 20$ & - & - & 250 & 212.5 & 2 \\
\hline Chen [21] & 12 & 0 & 0 & 0 & 1 & 8 & 3 & 0 & - & 0 & $9 / 12$ & $3 / 12$ & - & 28 & 1 & 140 & 200 & - \\
\hline Chen [22] & 35 & 0 & 0 & 3 & 9 & 9 & - & - & $14 \#$ & - & $34 / 35$ & $1 / 35$ & - & 33 & 0 & - & - & - \\
\hline
\end{tabular}

Duration from last dose of immunotherapy; ${ }^{\#}$ included sleeve and Pancoast tumor resections; IQR, Interquartile range; MIS, minimally invasive surgery. 


\subsection{Radiological Response}

Radiological response outcomes were consistently reported according to the Response Evaluation Criteria in Solid Tumors (RECIST) criteria [25]. Overall, 0.8\% (95\% confidence interval (CI): $0.1-6.3 \%$ ) of patients reported complete response, $48.0 \%$ (95\% CI: 36.0-60.2\%) reported partial response, $35.9 \%$ (95\% CI: $22.3-52.3 \%$ ) reported stable disease, and $3.6 \%$ (95\% CI: $1.5-8.1 \%$ ) reported progressive disease, as presented in Figure 1.

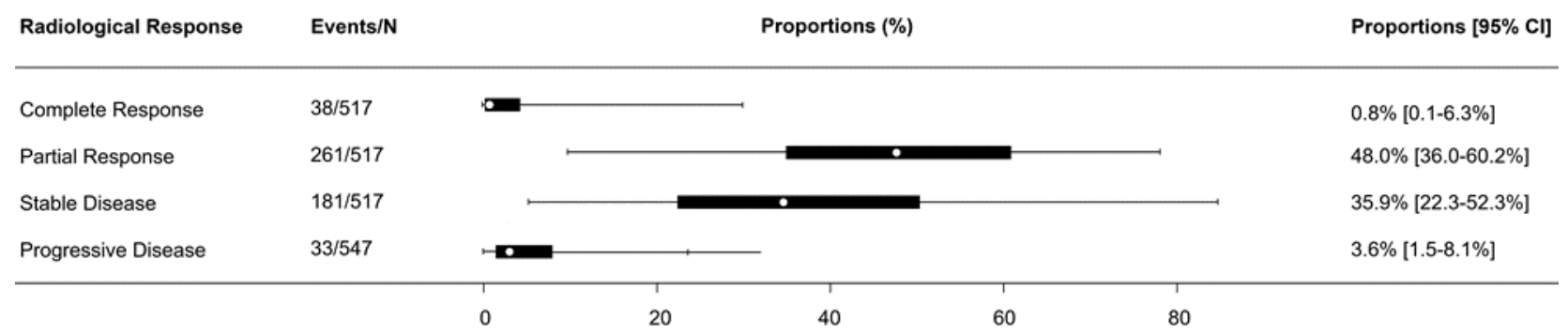

Figure 1. Forest plot summarizing the proportion of patients with radiological response after neoadjuvant immunotherapy for resectable non-small cell lung cancer.

\subsection{Pathological Response}

Pathological response outcomes were reported as 'major pathological response' (MPR) when less than $10 \%$ of the viable tumor was identified in the primary lesion, and 'complete pathological response' (pCR) when no viable tumor was identified. However, some studies specifically reported $\mathrm{pCR}$ when both the primary lesion as well as the sampled lymph nodes were free from any viable tumor $[5-7,9,10,12-14,17,19,22]$, whereas others did not specify if nodal assessments were performed for pathological responses $[8,11,15,16,18,20,21]$. In addition, two studies defined MPR and $\mathrm{PCR}$ as being mutually exclusive, whereby patients who achieved a complete pathological response were not included within the group defined as a major pathological response $[9,21]$. The pathological response data from these studies were adjusted during statistical analysis to conform with other reports that included $\mathrm{pCR}$ patients within the MPR group. From the available data, 52\% (95\% CI: $42-62 \%$; I ${ }^{2}=73 \%$ ) of patients who underwent surgery following neoadjuvant immunotherapy achieved MPR, $24 \%$ (95\% CI, $17-34 \%$; $\mathrm{I}^{2}=76 \%$ ) achieved pCR of the primary lesion, and $20 \%$ (95\% CI: 9-36\%; $\mathrm{I}^{2}=86 \%$ ) achieved $\mathrm{pCR}$ of both the primary lesion as well as the sampled lymph nodes. A summary of radiological and pathological response rates is presented in Table 4, and meta-analyzed forest plots of MPR, pCR, and pCR, including lymph nodes, are presented in Figure 2A-C.

\subsection{Mortality and Morbidity}

Overall, four deaths $(0.6 \%)$ were reported within 30 days of surgery from all selected studies. However, some studies reported deaths within the same admission beyond 30 days [5]. Adverse events were commonly reported according to the grades of severity, ranging from grade 1-5. The most common surgical complications included prolonged air leak, pneumonia, atrial arrhythmias, chylothorax, and recurrent laryngeal nerve injury. The most common treatment-related adverse events included fatigue, anorexia, nausea, alopecia, neutropenia, and rash. A summary of surgical and treatment-related adverse events, including specified grade 3-5 adverse events, are summarized in Supplementary Tables S1 and S2, respectively, and illustrated in Supplementary Figures S2 and S3. Adverse events were only tabulated if they were reported in three or more individual studies, unless the severity of an adverse event was $\geq 3$, in which case they were included irrespective of frequency. 
A

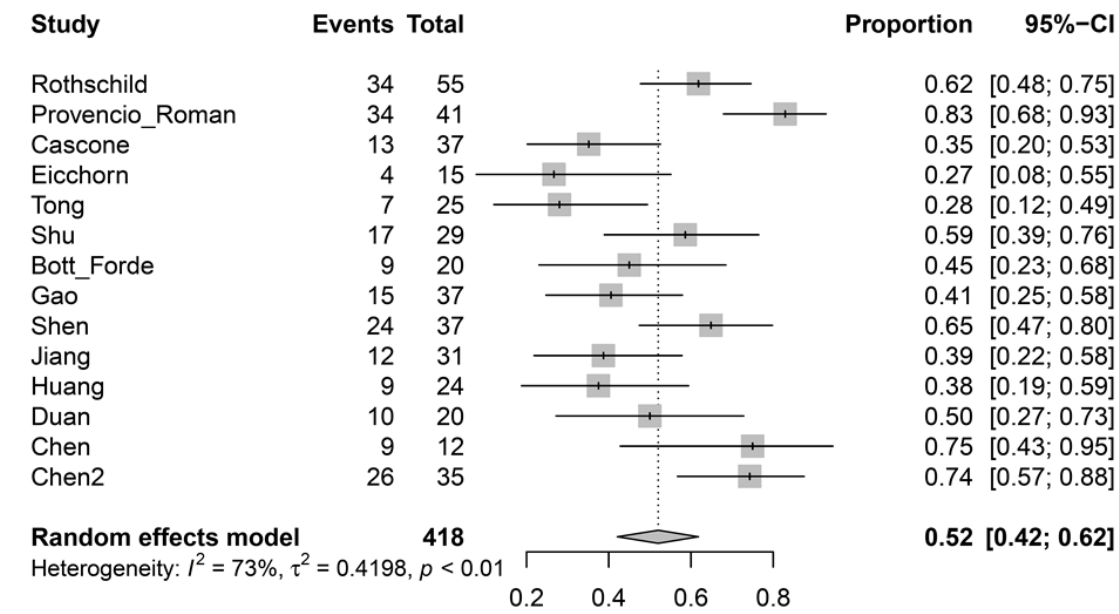

B

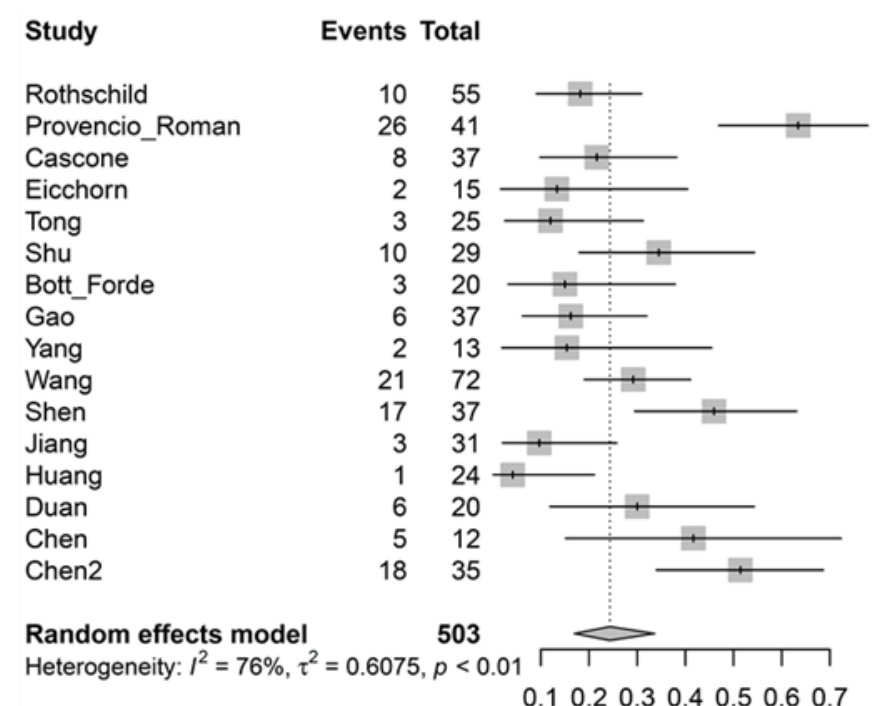

Proportion $\quad 95 \%-\mathrm{Cl}$

$0.18[0.09 ; 0.31]$

$0.63[0.47 ; 0.78]$

$0.22[0.10 ; 0.38]$

$0.13[0.02 ; 0.40]$

$0.12[0.03 ; 0.31]$

$0.34[0.18 ; 0.54]$

$0.15[0.03 ; 0.38]$

$0.16[0.06 ; 0.32]$

$0.15[0.02 ; 0.45]$

$0.29[0.19 ; 0.41]$

$0.46[0.29 ; 0.63]$

$0.10[0.02 ; 0.26]$

$0.04[0.00 ; 0.21]$

$0.30[0.12 ; 0.54]$

$0.42[0.15 ; 0.72]$

$0.51[0.34 ; 0.69]$

$0.24[0.17 ; 0.34]$

C

\section{Study}

Rothschild

Provencio_Roman

Eicchorn

Tong

Bott_Forde

Gao

Shen

Huang

Chen2

Random effects model 289
Heterogeneity: $I^{2}=86 \%, \tau^{2}=1.3014, p<0.01$

Events Total

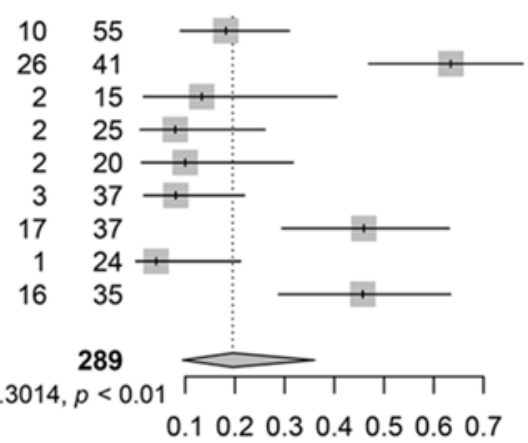

Proportion $\quad 95 \%-\mathrm{Cl}$

$0.18[0.09 ; 0.31]$

$0.63[0.47 ; 0.78]$

$0.13[0.02 ; 0.40]$

$0.08[0.01 ; 0.26]$

$0.10[0.01 ; 0.32]$

$0.08[0.02 ; 0.22]$

$0.46[0.29 ; 0.63]$

$0.04[0.00 ; 0.21]$

$0.46[0.29 ; 0.63]$

$0.20[0.09 ; 0.36]$

Figure 2. (A) Forest plot summarizing the proportion of patients with major pathological responses after neoadjuvant immunotherapy for resectable non-small cell lung cancer. (B) Forest plot summarizing the proportion of patients with complete pathological response of the primary tumor after neoadjuvant immunotherapy for resectable non-small cell lung cancer. (C) Forest plot summarizing the proportion of patients with complete pathological response of the primary tumor and sampled lymph nodes after neoadjuvant immunotherapy for resectable non-small cell lung cancer. 
Table 4. A summary of radiological and pathological responses after neoadjuvant immunotherapy for patients with resectable non-small cell lung cancer.

\begin{tabular}{|c|c|c|c|c|c|c|c|}
\hline \multirow[b]{2}{*}{ Study } & \multicolumn{4}{|c|}{ Radiological Response * } & \multicolumn{3}{|c|}{ Pathological Response } \\
\hline & CR & PR & SD & PD & Major Pathological Response & $\begin{array}{c}\text { Complete Pathological Response } \\
\text { Primary Lesion }\end{array}$ & $\begin{array}{l}\text { Complete Pathological Response } \\
\text { Primary Lesion + Nodes }\end{array}$ \\
\hline Rothschild [5] & $4 / 62$ & $32 / 62$ & $16 / 62$ & $7 / 62$ & $34 / 55$ & $10 / 55$ & $10 / 55$ \\
\hline $\begin{array}{l}\text { Provencio [6] } \\
\text { Roman [7] }\end{array}$ & $2 / 46$ & $33 / 46$ & $11 / 46$ & 0 & $34 / 41$ & $26 / 41$ & $26 / 41$ \\
\hline Cascone [8] & $1 / 44$ & $8 / 44$ & $28 / 44$ & $6 / 44$ & $13 / 37$ & $8 / 37$ & - \\
\hline Eicchorn [9] & 0 & $4 / 15$ & $10 / 15$ & 0 & $4 / 15^{\wedge}$ & $2 / 15$ & $2 / 15$ \\
\hline Tong [10] & - & - & - & $1 / 30$ & $7 / 25$ & $3 / 25$ & $2 / 25$ \\
\hline Shu [11] & 0 & $19 / 30$ & $9 / 30$ & $2 / 30$ & $17 / 29$ & $10 / 29$ & - \\
\hline $\begin{array}{l}\text { Bott [12] } \\
\text { Forde [13] }\end{array}$ & 0 & $2 / 21$ & $18 / 21$ & $1 / 21$ & $9 / 20$ & $3 / 20$ & $2 / 20$ \\
\hline Gao [14] & 0 & $8 / 40$ & $28 / 40$ & $4 / 40$ & $15 / 37$ & $6 / 37$ & $3 / 37$ \\
\hline Yang [15] & 0 & $14 / 24$ & $2 / 24$ & $8 / 24$ & - & $2 / 13$ & - \\
\hline Wang [16] & $21 / 72$ & $47 / 72$ & $3 / 72$ & $1 / 72$ & - & $21 / 72$ & - \\
\hline Shen [17] & $10 / 37$ & $22 / 37$ & $5 / 37$ & 0 & $24 / 37$ & $17 / 37$ & $17 / 37$ \\
\hline Jiang [18] & 0 & $24 / 31$ & $5 / 31$ & $2 / 31$ & $12 / 31$ & $3 / 31$ & - \\
\hline Huang [19] & 0 & $8 / 25$ & $16 / 25$ & $1 / 25$ & $9 / 24$ & $1 / 24$ & $1 / 24$ \\
\hline Duan [20] & 0 & $17 / 23$ & $6 / 23$ & 0 & $10 / 20$ & $6 / 20$ & - \\
\hline Chen [22] & 0 & $17 / 35$ & $18 / 35$ & 0 & $26 / 35$ & $18 / 35$ & $16 / 35$ \\
\hline Total & $0.8 \%$ & $48.0 \%$ & $35.9 \%$ & $3.6 \%$ & $52.0 \%$ & $24.3 \%$ & $19.6 \%$ \\
\hline
\end{tabular}

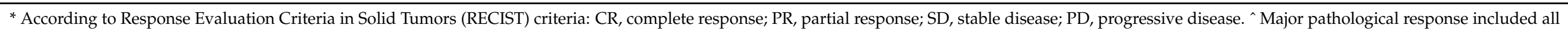
patients with $<10 \%$ viable tumor. 


\subsection{Overall Survival and Disease-Free Survival}

Six studies provided survival data in the form of Kaplan-Meier graphs, but a statistical summary of these data was not possible due to different timeframes of survival calculation $[5,6,8,11,12,22]$. Survival was calculated from the time of registration [5], diagnosis [6], randomization [8], treatment initiation [11], surgery [13], or unspecified reasons [22]. The follow-up periods of these studies were also limited, ranging from 13-29 months.

\section{Discussion}

The present systematic review and meta-analysis aimed to provide an overview of the existing evidence for patients who underwent neoadjuvant immunotherapy for resectable NSCLC. The key findings of the study identified a major pathological response rate of $52 \%$ and a complete pathological response of $24 \%$. These values compared favorably to historical data for chemotherapy, which reported estimated rates of MPR and pCR as $22 \%$ and $4 \%$, respectively $[26,27]$. When the sampled lymph nodes as well as the primary lesions were assessed by selected studies, the meta-analysis of $\mathrm{pCR}$ for neoadjuvant immunotherapy was $20 \%$. The radiological response was less consistent, with $83.9 \%$ of patients reporting either stable disease or partial regression according to RECIST criteria. The lack of correlation between pathological and radiological responses can be partially attributed to the pseudoprogression phenomenon, whereby the infiltration of T-cells and peritumoral inflammation were associated with the increased size and activity of lesions on imaging, but favorable pathological responses in histopathology [12]. The incidence of this phenomenon in the recent NEOSTAR and NEOMUN trials was low, and its clinical significance remains to be seen $[6,7,9]$. The present study demonstrated the feasibility and safety of immune checkpoint inhibitors when given prior to surgery, with $96 \%$ of patients undergoing surgery after systemic treatment, and a surgical delay rate of $2.0 \%$. The overall 30 -day mortality rate was $0.6 \%$ across all studies, and surgical morbidities were similar in type and frequency to contemporary series of thoracic resections without neoadjuvant immunotherapy [28,29].

Surgical resection was performed by open thoracotomy in $51.7 \%$ of all cases, including in $12.4 \%$ patients who were converted from an intended minimally invasive approach. These findings compared favorably to outcomes reported by the National Cancer Data Base, which reported a thoracotomy rate of $73.2 \%$ and a conversion rate of $18.9 \%$ for VATS and $10.3 \%$ for robotic VATS [30]. For patients with advanced-stage NSCLC who underwent neoadjuvant chemotherapy, outcomes from tertiary institutions reported conversion rates of $26 \%$ after attempted VATS or robotic VATS [29,31]. The higher proportion of patients who were able to complete their operations via a minimally invasive approach identified in the present systematic review was likely due to the selection of specialized academic centers recruited for clinical trials. Encouragingly, the completeness of resection (R0) was achieved in $97.3 \%$ of all patients, and the pneumonectomy rate was $8.6 \%$, which was relatively low compared to other series that reported $15.8-17.6 \%$ for patents who had neoadjuvant chemotherapy $[29,32]$. Technical challenges after neoadjuvant immunotherapy included increased fibrosis, adhesions, and granulomatous changes found within lymph nodes that Cascone termed 'nodal immune flare' [8], which could make the dissection around critical structures difficult and unsafe. Similar findings were reported by Bott, who also described dense adhesions surrounding the fissure and aorta [12].

Several limitations should be acknowledged from the present study, and results should be interpreted with caution. Some endpoints were inconsistently reported by studies identified in the present systematic review. Most importantly, a complete pathological response was defined as 'no viable tumor within the resected specimen', but there was variable reporting on whether the resected lymph nodes were also assessed. Travis advocated for a systematic approach to evaluate sampled nodes, particularly in the context of clinical trials, to confirm an absence of a tumor within the nodes (ypN0) after neoadjuvant systemic therapy [33]. Several studies [10,12-14,22] reported the presence of a tumor in nodal specimens when the primary lesions had $\mathrm{pCR}$, and future studies should routinely assess and report 
on the pathological response of nodal tissue to understand their incidence and clinical significance. The variations in patient inclusion criteria, neoadjuvant treatment regimen, and subsequent adjuvant therapy may impact the overall and disease-free survival outcomes, which should also be reported from well-defined timeframes, such as the time of operation. The follow-up periods were relatively short, and only limited survival data have been published to date. Finally, there is a potential publication bias, as the abstracts identified in our screening process reported the early termination of trials due to lack of efficacy or excessive postoperative mortality, but their data were not included for quantitative analysis as they did not meet the study selection criteria [34,35].

Many challenging questions remain about the utility of immunotherapy for patients with resectable NSCLC. The potential prognostic value of PD-L1 (programmed deathligand 1) was evaluated at separate cut-off points and measured against different surrogate endpoints such as MPR and pCR [5-9,22]. Such variations between studies dilute the strength of data interpretation, and the impact on overall survival and justification for patient selection remains uncertain. Future studies evaluating PD-L1 should routinely report on standardized endpoints such as overall survival and PCR, with accepted thresholds such as $<1 \%$ vs. $>1 \%$. The type of immune check inhibitor, number of cycles, and additional prescription of chemotherapy in both neoadjuvant and adjuvant settings varied between studies. The optimal treatment regimen is most likely personalized to the individual patient based on predictive factors not yet elucidated from the published data. Larger studies with longer follow-up may answer some of these questions, and novel predictors of response, such as microbiome analysis and tumor mutational burden should be further examined $[8,13]$.

Supplementary Materials: The following are available online at https:/ /www.mdpi.com/article/10 $.3390 /$ curroncol28060395/s1, Figure S1: PRIMSA flow chart detailing the literature search process for studies on neoadjuvant immunotherapy and surgery for non-small cell lung cancer; Figure S2: Post-surgical adverse events for patients with resectable non-small cell lung cancer after neoadjuvant immunotherapy; Figure S3: Treatment-related adverse events for patients with resectable non-small cell lung cancer after neoadjuvant systemic therapy; Table S1: Postoperative surgical adverse events of patients who underwent neoadjuvant immunotherapy and resection for non-small cell lung cancer; Table S2 A summary of treatment-related adverse events for patients who underwent neoadjuvant immunotherapy for resectable non-small cell lung cancer.

Author Contributions: C.C., conceptualization, data curation, formal analysis, investigation, methodology, project administration, resources, supervision, validation, visualization, writing, editing; A.L., data curation, writing; M.B., formal analysis, supervision, writing, editing; C.-F.J.Y., formal analysis, supervision, writing, editing; D.G., formal analysis, supervision, writing, editing; F.M., formal analysis, supervision, writing, editing; D.H.T., software, statistical analysis, validation, writing; A.G.: data curation, formal analysis, methodology, writing, editing. All authors have read and agreed to the published version of the manuscript.

Funding: This research received no external funding.

Conflicts of Interest: Professor Melfi and A/Prof Cao are proctors for Intuitive Surgical. Other authors have no conflict of interest.

$\begin{array}{ll}\text { Abbreviations } \\ \text { ICI } & \text { immune checkpoint inhibitor } \\ \text { NSCLC } & \text { non-small cell lung cancer } \\ \text { CI } & \text { confidence intervals } \\ \text { VATS } & \text { video assisted thoracoscopic surgery } \\ \text { RECIST } & \text { response evaluation criteria in solid tumors } \\ \text { MPR } & \text { major pathological response } \\ \text { pCR } & \text { complete pathological response } \\ \text { PD-L1 } & \text { programmed death-ligand 1 }\end{array}$




\section{References}

1. Herbst, R.S.; Giaccone, G.; de Marinis, F.; Reinmuth, N.; Vergnenegre, A.; Barrio, C.H.; Morise, M.; Felip, E.; Andric, Z.; Geater, S.; et al. Atezolizumab for First-Line Treatment of PD-L1-Selected Patients with NSCLC. N. Engl. J. Med. 2020, 383, 1328-1339. [CrossRef] [PubMed]

2. Group NM-aC. Preoperative chemotherapy for non-small-cell lung cancer: A systematic review and meta-analysis of individual participant data. Lancet 2014, 383, 1561-1571. [CrossRef]

3. Liu, J.; Blake, S.J.; Yong, M.C.; Harjunpaa, H.; Ngiow, S.F.; Takeda, K.; Young, A.; O'Donnell, J.S.; Allen, S.; Smyth, M.J.; et al. Improved Efficacy of Neoadjuvant Compared to Adjuvant Immunotherapy to Eradicate Metastatic Disease. Cancer Dis. 2016, 6, 1382-1399. [CrossRef] [PubMed]

4. Lin, L.; Chu, H. Meta-analysis of Proportions Using Generalized Linear Mixed Models. Epidemiology 2020, 31, 713-717. [CrossRef] [PubMed]

5. Rothschild, S.I.; Zippelius, A.; Eboulet, E.I.; Prince, S.S.; Betticher, D.; Bettini, A.; Fruh, M.; Joerger, M.; Ladinois, D.; Gelpke, H.; et al. SAKK 16/14: Durvalumab in Addition to Neoadjuvant Chemotherapy in Patients With Stage IIIA(N2) Non-Small-Cell Lung Cancer-A Multicenter Single-Arm Phase II Trial. J. Clin. Oncol. 2021, 39, 2872-2880. [CrossRef]

6. Provencio, M.; Nadal, E.; Insa, A.; Garcia-Campelo, M.R.; Casal-Rubio, J.; Domine, M.; Majem, M.; Rodriguez-Abreu, D.; Martinez-Marti, A.; Carpeno, J.D.C.; et al. Neoadjuvant chemotherapy and nivolumab in resectable non-small-cell lung cancer (NADIM): An open-label, multicentre, single-arm, phase 2 trial. Lancet Oncol. 2020, 21, 1413-1422. [CrossRef]

7. Romero Román, A.; Campo-Cañaveral de la Cruz, J.L.; Macía, I.; Campuzano, I.E.; Almanzar, S.F.; Roel, M.D.; Munoz, C.G.; Garcia Fontan, E.M.; Trueba, I.M.; Vielva, L.R.; et al. Outcomes of surgical resection after neoadjuvant chemoimmunotherapy in locally advanced stage IIIA non-small-cell lung cancer. Eur. J. Cardiothorac. Surg. 2021, 60, 81-88. [CrossRef]

8. Cascone, T.; William, W.N.; Weissferdt, A., Jr.; Leung, C.H.; Lin, H.Y.; Pataer, A.; Godoy, M.C.B.; Carter, B.W.; Federico, L.; Reuben, A.; et al. Neoadjuvant nivolumab or nivolumab plus ipilimumab in operable non-small cell lung cancer: The phase 2 randomized NEOSTAR trial. Nat. Med. 2021, 27, 504-514. [CrossRef]

9. Eichhorn, F.; Klotz, L.V.; Kriegsmann, M.; Bischoff, H.; Schneider, M.A.; Muley, T.; Kriegsmann, K.; Haberkorn, U.; Heussel, C.P.; Savai, R.; et al. Neoadjuvant anti-programmed death-1 immunotherapy by pembrolizumab in resectable non-small cell lung cancer: First clinical experience. Lung Cancer 2021, 153, 150-157. [CrossRef]

10. Tong, B.C.; Gu, L.; Wang, X.; Wigle, D.A.; Phillips, J.D.; Harpole, D.H.; Klapper, J.A.; Sporn, T.; Ready, N.E.; D’Amico, T.A. Perioperative outcomes of pulmonary resection after neoadjuvant pembrolizumab in patients with non-small cell lung cancer. J. Thorac. Cardiovasc. Surg. 2021. [CrossRef]

11. Shu, C.A.; Gainor, J.F.; Awad, M.M.; Chiuzan, C.; Grigg, C.M.; Pabani, A.; Garofano, R.F.; Stoopler, M.B.; Cheng, S.K.; White, A.; et al. Neoadjuvant atezolizumab and chemotherapy in patients with resectable non-small-cell lung cancer: An open-label, multicentre, single-arm, phase 2 trial. Lancet Oncol. 2020, 21, 786-795. [CrossRef]

12. Bott, M.J.; Yang, S.C.; Park, B.J.; Adusumilli, P.S.; Rusch, V.W.; Isbell, J.M.; Downey, R.J.; Brahmer, J.R.; Battafarano, R.; Bush, E.; et al. Initial results of pulmonary resection after neoadjuvant nivolumab in patients with resectable non-small cell lung cancer. J. Thorac. Cardiovasc. Surg. 2019, 158, 269-276. [CrossRef] [PubMed]

13. Forde, P.M.; Chaft, J.E.; Smith, K.N.; Anagnostou, V.; Cottrell, T.R.; Hellman, M.D.; Zahurak, M.; Yang, S.C.; Jones, D.R.; Broderick, S.; et al. Neoadjuvant PD-1 Blockade in Resectable Lung Cancer. N. Engl. J. Med. 2018, 378, 1976-1986. [CrossRef] [PubMed]

14. Gao, S.; Li, N.; Gao, S.; Xue, Q.; Ying, J.; Wang, S.; Tao, X.; Zhao, J.; Mao, Y.; Wang, B.; et al. Neoadjuvant PD-1 inhibitor (Sintilimab) in NSCLC. J. Thorac. Oncol. 2020, 15, 816-826. [CrossRef]

15. Yang, C.J.; McSherry, F.; Mayne, N.R.; Wang, X.; Berry, M.F.; Tong, B.; Harpole, D.H.; D'Amico, T.A.; Christensen, J.D.; Ready, N.E.; et al. Surgical Outcomes After Neoadjuvant Chemotherapy and Ipilimumab for Non-Small Cell Lung Cancer. Ann. Thorac. Surg. 2018, 105, 924-929. [CrossRef]

16. Wang, J.; Li, J.; Cai, L.; Chen, S.; Jiang, Y. The safety and efficacy of neoadjuvant programmed death 1 inhibitor therapy with surgical resection in stage IIIA non-small cell lung cancer. Ann. Transl. Med. 2021, 9, 486. [CrossRef]

17. Shen, D.; Wang, J.; Wu, J.; Chen, S.; Li, J.; Liu, J.; Chen, Q.; Jiang, Y. Neoadjuvant pembrolizumab with chemotherapy for the treatment of stage IIB-IIIB resectable lung squamous cell carcinoma. J. Thorac. Dis. 2021, 13, 1760-1768. [CrossRef]

18. Jiang, L.; Huang, J.; Jiang, S.; Rong, W.; Shen, Y.; Li, C.; Tian, Y.; Ning, J.; Chen, X.; Yang, Y.; et al. The surgical perspective in neoadjuvant immunotherapy for resectable non-small cell lung cancer. Cancer Immunol. Immunother. 2021, 70, $2313-2321$. [CrossRef]

19. Huang, Z.; Wu, Z.; Qin, Y.; Zhao, Y.; Xuan, Y.; Qiu, T.; Liu, A.; Dong, T.; Su, W.; Du, W.; et al. Perioperative safety and feasibility outcomes of stage IIIA-N2 non-small cell lung cancer following neoadjuvant immunotherapy or neoadjuvant chemotherapy: A retrospective study. Ann. Transl. Med. 2021, 9, 685. [CrossRef]

20. Duan, H.; Wang, T.; Luo, Z.; Tong, L.; Dong, X.; Zhang, Y.; Afzal, M.Z.; Correale, P.; Liu, H.; Jiang, T.; et al. Neoadjuvant programmed cell death protein 1 inhibitors combined with chemotherapy in resectable non-small cell lung cancer: An open-label, multicenter, single-arm study. Transl. Lung Cancer Res. 2021, 10, 1020-1028. [CrossRef]

21. Chen, T.; Ning, J.; Campisi, A.; Dell'Amore, A.; Ciarrocchi, A.P.; Li, Z.; Song, L.; Huang, J.; Yang, Y.; Stella, F.; et al. Neoadjuvant PD-1 inhibitors and chemotherapy for locally advanced NSCLC: A retrospective study. Ann. Thorac. Surg. 2021. [CrossRef] 
22. Chen, Y.; Yan, B.; Xu, F.; Hui, Z.; Zhao, G.; Liu, J.; Zhang, H.; Zeng, Z.; Zhang, R.; Provencio, M.; et al. Neoadjuvant chemoimmunotherapy in resectable stage IIIA/IIIB non-small cell lung cancer. Transl. Lung Cancer Res. 2021, 10, $2193-2204$. [CrossRef] [PubMed]

23. Goldstraw, P.; Chansky, K.; Crowley, J.; Rami-Porta, R.; Asamura, H.; Eberhardt, W.E.E.; Nicholson, A.G.; Groome, P.; Mitchell, A.; Bolejack, V. The IASLC Lung Cancer Staging Project: Proposals for Revision of the TNM Stage Groupings in the Forthcoming (Eighth) Edition of the TNM Classification for Lung Cancer. J. Thorac. Oncol. 2016, 11, 39-51. [CrossRef]

24. Goldstraw, P.; Crowley, J.; Chansky, K.; Giroux, D.J.; Groome, P.A.; Rami-Porta, R.; Postmus, P.E.; Rusch, V.; Sobin, L. The IASLC Lung Cancer Staging Project: Proposals for the revision of the TNM stage groupings in the forthcoming (seventh) edition of the TNM Classification of malignant tumours. J. Thorac. Oncol. 2007, 2, 706-714. [CrossRef] [PubMed]

25. Eisenhauer, E.A.; Therasse, P.; Bogaerts, J.; Schwartz, L.H.; Sargent, D.; Ford, R.; Dancey, J.; Arbuch, S.; Gwyther, S.; Mooney, M.; et al. New response evaluation criteria in solid tumours: Revised RECIST guideline (version 1.1). The IASLC Lung Cancer Staging Project: Proposals for the revision of the TNM stage groupings in the forthcoming (seventh) edition of the TNM Classification of malignant tumours. The IASLC Lung Cancer Staging Project: Proposals for Revision of the TNM Stage Groupings in the Forthcoming (Eighth) Edition of the TNM Classification for Lung Cancer. Eur. J. Cancer 2009, 45, $228-247$.

26. Chaft, J.E.; Rusch, V.; Ginsberg, M.S.; Paik, P.K.; Finley, D.J.; Kris, M.G.; Price, K.A.R.; Azzoli, C.G.; Fury, M.G.; Riely, G.J.; et al. Phase II trial of neoadjuvant bevacizumab plus chemotherapy and adjuvant bevacizumab in patients with resectable nonsquamous non-small-cell lung cancers. J. Thorac. Oncol. 2013, 8, 1084-1090. [CrossRef] [PubMed]

27. Hellmann, M.D.; Chaft, J.E.; William, W.N., Jr.; Rusch, V.; Pisters, K.M.W.; Kalhor, N.; Pataer, A.; Travis, W.D.; Swisher, S.G.; Kris, M.G.; et al. Pathological response after neoadjuvant chemotherapy in resectable non-small-cell lung cancers: Proposal for the use of major pathological response as a surrogate endpoint. Lancet Oncol. 2014, 15, e42-e50. [CrossRef]

28. Zhang, Z.; Mostofian, F.; Ivanovic, J.; Gilbert, S.; Maziak, D.E.; Shamji, F.M.; Sundaresan, S.; Villeneuve, P.J.; Seely, A.J.E. All grades of severity of postoperative adverse events are associated with prolonged length of stay after lung cancer resection. J. Thorac. Cardiovasc. Surg. 2018, 155, 798-807. [CrossRef] [PubMed]

29. Dy, G.K.; Bogner, P.N.; Tan, W.; Demmy, T.L.; Farooq, A.; Chen, H.; Yendamuri, S.S.; Nwogu, C.E.; Bushunow, P.W.; Gannon, J.; et al. Phase II Study of Perioperative Chemotherapy with Cisplatin and Pemetrexed in Non-Small-Cell Lung Cancer. J. Thorac. Oncol. 2014, 9, 222-230. [CrossRef] [PubMed]

30. Rajaram, R.; Mohanty, S.; Bentrem, D.J.; Pavey, E.S.; Odell, D.D.; Bharat, A.; Bilimoria, K.Y.; DeCamp, M.M. Nationwide Assessment of Robotic Lobectomy for Non-Small Cell Lung Cancer. Ann. Thorac. Surg. 2017, 103, 1092-1100. [CrossRef] [PubMed]

31. Park, B.J.; Yang, H.X.; Woo, K.M.; Sima, C.S. Minimally invasive (robotic assisted thoracic surgery and video-assisted thoracic surgery) lobectomy for the treatment of locally advanced non-small cell lung cancer. J. Thorac. Dis. 2016, 8, S406-S413. [CrossRef] [PubMed]

32. Nakanishi, R.; Fujino, Y.; Yamashita, T.; Shinohara, S.; Oyama, T. Thoracoscopic anatomic pulmonary resection for locally advanced non-small cell lung cancer. Ann. Thorac. Surg. 2014, 97, 980-985. [CrossRef] [PubMed]

33. Travis, W.D.; Dacic, S.; Wistuba, I.; Sholl, L.; Adusumilli, P.; Bubendorf, L.; Bunn, P.; Cascone, T.; Chaft, J.; Chen, G.; et al. IASLC Multidisciplinary Recommendations for Pathologic Assessment of Lung Cancer Resection Specimens After Neoadjuvant Therapy. J. Thorac. Oncol. 2020, 15, 709-740. [CrossRef] [PubMed]

34. Wislez, M.; Mazières, J.; Lavolé, A.; Zalcman, G.; Carre, O.; Egenod, T.; Caliandro, R.; Gervais, R.; Jeannin, G.; Molinier, O.; et al. 12140 Neoadjuvant durvalumab in resectable non-small cell lung cancer (NSCLC): Preliminary results from a multicenter study (IFCT-1601 IONESCO). Ann. Oncol. 2020, 31, S794. [CrossRef]

35. Besse, B.; Adam, J.; Cozic, N.; Chaput-Gras, N.; Planchard, D.; Mezquita, L.; Remon Masip, J.; Lavaud, P.; Naltet, C.; Gazzah, A.; et al. 1215O-SC Neoadjuvant atezolizumab (A) for resectable non-small cell lung cancer (NSCLC): Results from the phase II PRINCEPS trial. Ann. Oncol. 2020, 31, S794-S795. [CrossRef] 